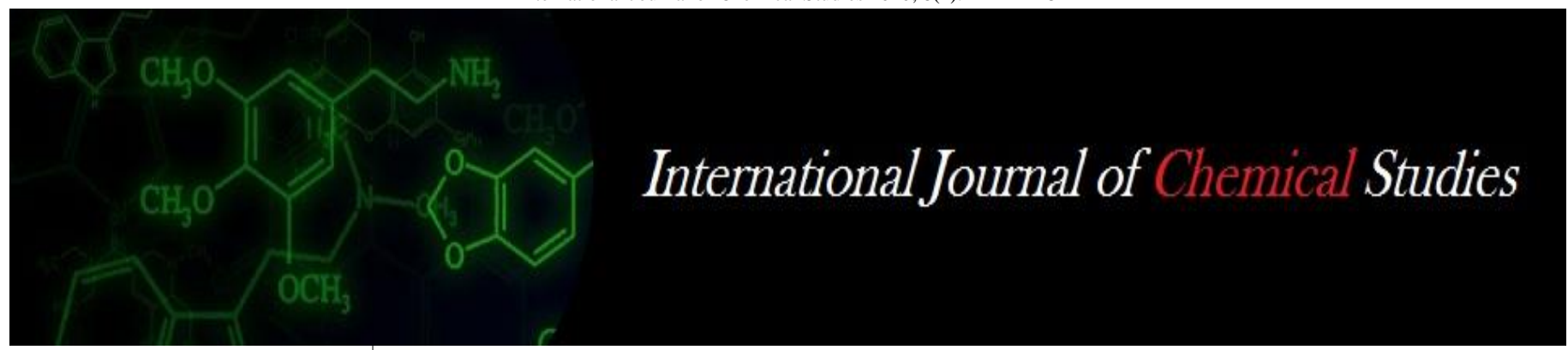

P-ISSN: 2349-8528

E-ISSN: 2321-4902

IJCS 2020; 8(1): 2122-2125

(C) 2020 IJCS

Received: 13-11-2019

Accepted: 15-12-2019

MR Ravikumar

Department of Plant Pathology, College of Agriculture,

Hanumanamatti, Taluk,

Ranebennur District, Haveri,

Karnataka, India

Vithal Navi

Department of Agricultural

Microbiology, College of

Agriculture, UAS, Dharwad,

Karnataka, India

\section{Evaluation of bio-efficacy and phytotoxicity of BAS 75101 F SC against early blight disease of tomato}

\section{MR Ravikumar and Vithal Navi}

\section{DOI: https://doi.org/10.22271/chemi.2020.v8.i1af.8582}

\begin{abstract}
Early blight disease in tomato is destructive in nature and reduces fruit yield. Fungicides were used to control early blight disease but still early blight disease occurs. Hence, for in search of good alternative fungicide to control early blight disease, field experiment on efficacy of BAS $75101 \mathrm{~F}$ SC against early blight disease was conducted in kharif season of 2017-18 and 2018-19. There were 7 treatments with six fungicides and control. Observations on per cent disease index (PDI), fruit yield and phytotoxicity of fungicides on tomato were recorded. In both 2017-18 and 2018-19, BAS 75101 F SC with a.i.(g) of 200 @ $500 \mathrm{ml}$ or g/ $500-750$ litres of water was found superior in reducing disease severity $(22.12 \%$ mean PDI) over other fungicides used. In 2017-18 and 2018-19, BAS 75101 F SC with a.i.(g) of 200 @ 500 $\mathrm{ml}$ or $\mathrm{g} / 500-750$ litres of water treated plants produced higher yield of tomato fruits $(19.41 \mathrm{t} / \mathrm{ha}, 19.80$ t/ha) over other fungicides. BAS 75101 F SC with a.i.(g) of $200 @ 500 \mathrm{ml}$ or g/ $500-750$ litres of water were not toxic to tomato plant in kharif season of 2017-18 and 2018-19. The results concluded that use of BAS 75101 F SC with a.i.(g) of $200 @ 500 \mathrm{ml}$ or g/ 500 - 750 litres of water resulted in reducing disease severity and improved yield.
\end{abstract}

Keywords: Bio-efficacy, phytotoxicity, BAS $75101 \mathrm{~F} \mathrm{SC}$, blight disease, tomato

\section{Introduction}

Tomato (Lycopersicon esculentum Mill.) is grown in Karnataka as important vegetable crop. Tomato is infected by Alternaria solani during its growth. This plant pathogen produces early blight disease in tomato which is destructive in nature and consequently reduces fruit yield of tomato. Several fungicides have been tested to control early blight disease in tomato (Sharma et al. 2018, Tiwari et al., 2004; Yadav and Dabbas, 2012; Sahu et al., 2013 and Saxena et al. 2016, Patel, and Chaudhary, 2010) ${ }^{[6,7,9,4,5,3]}$ but still early blight disease in tomato occurs and causes reduction in yield and economic loss to the farmers. Hence, in order to find out the good alternative fungicide to control early blight disease in tomato, the field experiment on the evaluation of bio-efficacy and pytoxicity of BAS $75101 \mathrm{~F} \mathrm{SC}$ against early blight disease of Tomato was conducted.

\section{Materials and methods}

Field experiment was conducted to evaluate the bio-efficacy and phytotoxicity of BAS 75101 F SC against early blight disease of tomato in farmer's field at Kakol village in Ranebennur taluk, Haveri district during kharif season in the year 2017-18 and 2018-19. Tomato variety used for the study was Arka Samrath. The soil type was black soil. The thirty days old tomato plants were transplanted at the spacing of $90 \mathrm{~cm}$ x $75 \mathrm{~cm}$. The plot size was 20 meter square. The tomato crop was grown under irrigated condition. The experiment was conducted in randomized block design with seven treatments and three replications. The treatments were T1: BAS 75101 F SC with a.i.(g) of $120 @ 300 \mathrm{ml}$ or g/ $500-750$ litres of water, T2 : BAS 75101 F SC with a.i.(g) of $160 @ 400 \mathrm{ml}$ or g/ 500 - 750 litres of water, T3 : BAS $75101 \mathrm{~F}$ SC with a.i.(g) of $200 @ 500 \mathrm{ml}$ or g/ 500 - 750 litres of water, T4 : BAS 75002 F 400g/l SC with a.i.(g) of $100 @ 250 \mathrm{ml}$ or g/ 500 - 750 litres of water, T5 : Pyraclostrobin $20 \%$ WG with a.i.(g) of $100 @ 500 \mathrm{ml}$ or g/ 500 litres of water, T6 : Mancozeb 75\% WP with a.i.(g) of 1500 @ $2000 \mathrm{ml}$ or $\mathrm{g} / 500$ litres of water and T7: Untreated control
Corresponding Author: MR Ravikumar Department of Plant Pathology, College of Agriculture, Hanumanamatti, Taluk, Ranebennur District, Haveri, Karnataka, India 
Type of Sprayer used to spray fungicides was Knap sack sprayer fitted with flood jet. Tomato crop was sprayed with fungicides at different stages of growth as per treatments. The first spray was given at flower formation stage. Subsequent 2 sprays were given at the interval of 15 days during kharif season of 2017-18 and 2018-19. Early blight disease severity was recorded in 5 plants for each plot at 30 and 45 days after transplanting (DAT) on 0 - 5 standard rating scale (0: No symptoms on the leaf, 1: 0-5 per cent area infected and covered by spot, no spot on petiole and branches, 2: 6-20 per cent leaf area infected and covered by spot, some spots on petiole and branches, 3: 21-40 per cent leaf area infected and covered by spot, spots also seen on petiole, branches, 4: 41-70 per cent leaf area infected and covered by spot, spots also seen on petiole. braches, stem and 5 : More than 71 per cent leaf area infected and covered by spot, spots also seen on petiole, branch, stem, fruits) and the scale was converted into disease severity (Per cent Disease Index i.e. PDI) using the formula given by wheeler (1969) ${ }^{[8]}$. Observations on fruit yield per plot were recorded. The data on disease severity and fruit yield were analysed statistically and presented (Gomez and Gomez, 1986) ${ }^{[2]}$.

$\mathrm{PDI}=\frac{\text { Sum of the individual disease ratings }}{\text { Number of fruits/leaves observed }} \mathrm{X} \frac{100}{\text { Maximum disease rating value }}$

\section{Phytotoxic effects of BAS 75101 F 400 g/l SC}

Field experiment was conducted in the field to study the phytotoxic effect of BAS $75101 \mathrm{~F} 400 \mathrm{~g} / 1 \mathrm{SC}$ on tomato in kharif season in the year 2017-18 and 2018-19. The treatments included were T1: BAS $75101 \mathrm{~F} \mathrm{SC}$ with a.i.(g) of $200 @ 500 \mathrm{ml}$ or $\mathrm{g} / 500$ - 750 litres of water, T2: BAS 75101 F SC with a.i.(g) of 400 @ $1000 \mathrm{ml}$ or g/ 500 - 750 litres of water and T3: untreated control with three replications. Phytotoxic symptoms of BAS $75101 \mathrm{~F} 400 \mathrm{~g} / \mathrm{l} \mathrm{SC}$ such as leaf tips and surface injury, wilting, necrosis, epinasty and hyponasty on plants were observed on $1^{\text {st }}$ day, $3^{\text {rd }}$ day, $5^{\text {th }}$ day, $7^{\text {th }}$ day and $10^{\text {th }}$ day after spray. The phytotoxic symptoms were recorded on $0-10$ scale $(0$ : No phytotoxicity, $1: 1-10,2$ : 11-20, $3: 21-30,4: 31-40,5: 41-50,6$ : 51-60, $7: 61-70,8$ : $71-80,9: 81-90$ and $10: 91-100 \%$ phytotoxicity) (CIB 1989) [1]. For this five plants were selected at random from each treatment and the total number of leaves and those showing phyto-toxicty were counted. The data collected were converted into percentage. The extent of phyto-toxicty was recorded.

\section{Results and Discussion}

\section{Percent disease index and fruit yield}

The results of the study showed that BAS $75101 \mathrm{~F} 400 \mathrm{~g} / \mathrm{l}$ SC, Pyraclostrobin 20\% WG and Mancozeb 75\% WP were found effective in reducing the disease index of early blight in tomato over untreated control in kharif season of 2017-18 and 2018-19 (Tables 1 and 2). However, among the different fungicides, BAS 75101 F SC with a.i.(g) of $200 @ 500 \mathrm{ml}$ or g/ 500 - 750 litres of water was found more effective in reducing the disease index of early blight in tomato in kharif season of 2017-18 and 2018-19. In 2017-18, BAS $75101 \mathrm{~F}$ SC with a.i.(g) of $200 @ 500 \mathrm{ml}$ or g/ 500 - 750 litres of water was found superior in reducing disease severity $(22.12$ $\%$ mean PDI) where as other fungicides BAS $75101 \mathrm{~F} \mathrm{SC}$ with a.i.(g) of $160 @ 500 \mathrm{ml}$ or g/ 500 - 750 litres of water, BAS 75101 F SC with a.i.(g) of 120 @ $500 \mathrm{ml}$ or g/ 500 750 litres of water, BAS $75002 \mathrm{~F} \mathrm{400g/l} \mathrm{SC} \mathrm{with} \mathrm{a.i.(g)} \mathrm{of}$ $100 @ 250 \mathrm{ml}$ or $\mathrm{g} / 500-750$ litres of water, Pyraclostrobin
$20 \%$ WG with a.i.(g) of $100 @ 500 \mathrm{ml}$ or g/ 500 litres of water and Mancozeb 75\% WP with a.i.(g) of $1500 @ 2000 \mathrm{ml}$ or g/ 500 litres of water showed 24.55, 26.19, 27.88, 29.9, and $30.89 \%$ mean PDI respectively. The maximum mean early blight disease severity (PDI) was recorded in untreated control plants (mean PDI of 48.37) (Table 1). In 2018-19, BAS 75101 F SC with a.i.(g) of 200 @ 500 ml or g/ $500-$ 750 litres of water was found superior in reducing disease severity (21.30\% mean PDI) where as other fungicides BAS 75101 F SC with a.i.(g) of $160 @ 500 \mathrm{ml}$ or g/ $500-750$ litres of water, BAS 75101 F SC with a.i.(g) of 120 @ 500 $\mathrm{ml}$ or $\mathrm{g} / 500$ - 750 litres of water, BAS $75002 \mathrm{~F} 400 \mathrm{~g} / \mathrm{l} \mathrm{SC}$ with a.i.(g) of $100 @ 250 \mathrm{ml}$ or g/ 500 - 750 litres of water, Pyraclostrobin 20\% WG with a.i.(g) of 100 @ $500 \mathrm{ml}$ or g/ 500 litres of water and Mancozeb 75\% WP with a.i.(g) of $1500 @ 2000 \mathrm{ml}$ or g/ 500 litres of water showed 23.28, $25.29,26.73,28.94$, and $29.97 \%$ mean PDI respectively. The maximum mean early blight disease severity (PDI) was recorded in untreated control plants (mean PDI of 45.37) (Table 2).

These findings were in agreement with results of previous experiments wherein fungicides used to control plant diseases (Sharma et al. 2018, Sahu et al., 2013 and Saxena et al. 2016) $[6,4,5]$. Fungicidal treatments reduced the disease intensity of early blight disease of tomato and among different fungicidal applications, application of carbendazim $12 \%+$ mancozeb 63 \%WP @ $0.2 \%$ (18.77) recorded the lowest percent disease intensity followed by difenoconazole 25 EC @ $0.025 \%$ (20.59) and propiconazole 25 EC @ $0.025 \%$ (21.52) (Sharma et al., 2018) [6]. Maximum disease reduction in tomato was recorded in tomato plants treated with Onestar $23 \% \mathrm{SC}$ and Amistar $23 \%$ SC (69-71\% recorded) (Saxena et al., 2016) ${ }^{[5]}$. Fungicide, Pristine 38\%WG @ 64+126g a.i. /ha (31.88\%) significantly reduced the disease followed by maccani 16\%WG@60+180g a.i./ha (33.31\%) (Sahu et al., 2013) ${ }^{[4]}$

Tomato plants treated with fungicides produced significantly higher yield compared to untreated control plants in both 2017-18 and 2018-19. The increased fruit yield due to fungicide treatment of tomato plants grown during kharif season of 2017-18 was 19.41 t/ha ( BAS $75101 \mathrm{~F} \mathrm{SC}$ with a.i.(g) of $200 @ 500 \mathrm{ml}$ or g/ 500 - 750 litres of water), 18.60 t/ha (BAS 75101 F SC with a.i.(g) of 160 @ $400 \mathrm{ml}$ or g/ 500 - 750 litres of water,), $18.27 \mathrm{t} / \mathrm{ha}$ (BAS $75101 \mathrm{~F}$ SC with a.i.(g) of $120 @ 300 \mathrm{ml}$ or g/ 500 - 750 litres of water), 17.83 t/ha (BAS 75002 F 400g/l SC with a.i.(g) of $100 @ 250 \mathrm{ml}$ or $\mathrm{g} / 500$ - 750 litres of water), $17.20 \mathrm{t} / \mathrm{ha}$ (Pyraclostrobin 20\% WG with a.i.(g) of $100 @ 500 \mathrm{ml}$ or g/ 500 litres of water), $16.36 \mathrm{t} / \mathrm{ha}$ (Mancozeb 75\% WP with a.i.(g) of $1500 @ 2000$ $\mathrm{ml}$ or $\mathrm{g} / 500$ litres of water) over the untreated control 13.55 t/ha. In 2018-19 also, similar trend of 2017-18 in the increased fruit yield due to fungicide treatment was observed. The increased fruit yield due to fungicide treatment in kharif season of 2017-18 was 19.80 t/ha (BAS $75101 \mathrm{~F} \mathrm{SC}$ with a.i.(g) of $200 @ 500 \mathrm{ml}$ or g/ 500 - 750 litres of water), 18.63 t/ha (BAS 75101 F SC with a.i.(g) of 160 @ 400 ml or g/ 500 - 750 litres of water,), $18.30 \mathrm{t} / \mathrm{ha}$ (BAS $75101 \mathrm{~F} \mathrm{SC}$ with a.i.(g) of $120 @ 300 \mathrm{ml}$ or g/ 500 - 750 litres of water), 17.85 t/ha (BAS 75002 F 400g/l SC with a.i.(g) of 100 @ $250 \mathrm{ml}$ or $\mathrm{g} / 500$ - 750 litres of water), $17.80 \mathrm{t} / \mathrm{ha}$ (Pyraclostrobin 20\% WG with a.i.(g) of $100 @ 500 \mathrm{ml}$ or g/ 500 litres of water), 16.72 t/ha (Mancozeb 75\% WP with a.i.(g) of $1500 @ 2000$ $\mathrm{ml}$ or $\mathrm{g} / 500$ litres of water) over the untreated control 13.82 t/ha.

Overall, data revealed that BAS $75101 \mathrm{~F} \mathrm{SC}$ with a.i.(g) of $200 @ 500 \mathrm{ml}$ or $\mathrm{g} / 500$ - 750 litres of water was found 
effective and superior in increasing the tomato fruit yield due to reduction of PDI over other formulations. The increased fruit yield due to fungicide application was due to control of early blight disease which might have resulted in better development of foliage of tomato and consequently higher fruit yield in plants. These results were in agreement with previous experiments wherein the increased fruit yield of tomato in plants treated with various fungicides was reported (Sharma et al., 2018., Saxena et al., 2016 and Sahu et al., 2013) ${ }^{[6,4,5]}$. Among different fungicides, the highest yield of tomato fruits was recorded with carbendazim $12 \%+$ mancozeb $63 \%$ WP @ $0.2 \%(35257 \mathrm{~kg} / \mathrm{ha})$ followed by propiconazole 25 EC @ $0.025 \%$ (32328 $\mathrm{kg} / \mathrm{ha})$ and difenoconazole 25 EC @ $0.025 \%$ (32202 kg/ha) (Sharma et al., 2018) ${ }^{[6]}$. Fungicidal treatments (Onestar $23 \%$ SC and Amistar $23 \%$ SC) enhanced yield by 1.39 fold (Saxena et al., 2016) [5]. Increase in the fruit yield of tomato due to application fungicide of Pristine 38\%WG @ 64+126g a.i. ha) (33.50 tonnes/ha) and of maccani 16\%WG @ 80+ 240g a.i./ha) (32.44 tonnes/ha) as compared to a maximum disease $(76.2 \%)$ and minimum yield of only 21.15 tonnes/ha in control was reported (Sahu et al., 2013) ${ }^{[4]}$. This information could be used in disease management program for controlling early blight of tomato.

\section{Phyto-toxicity study}

Phyto-toxicity studies of BAS 75101 F SC with a.i. (g) of $200 @ 500 \mathrm{ml}$ or g/ 500 - 750 litres of water and BAS 75101 F SC with a.i.(g) of 400 @ $1000 \mathrm{ml}$ or g/ 500 - 750 litres of water revealed that these were not toxic to tomato plant in kharif season of 2017-18 and 2018-19 (Tables 3 and 4). There were no visual symptoms of phyto-toxicty in terms of leaf tips and surface injury, wilting, necrosis, epinasty and hyponasty on tomato plants treated with BAS $75101 \mathrm{~F} \mathrm{SC}$ with a.i.(g) of $200 @ 500 \mathrm{ml}$ or g/ $500-750$ litres of water (T1) and BAS 75101 F SC with a.i.(g) of 400 @ $1000 \mathrm{ml}$ or g/ $500-750$ litres of water (T2) on 1st day, 3rd day, 5th day, 7th day and 10th day after spray This study indicated that BAS $75101 \mathrm{~F}$ SC with a.i.(g) of $200 @ 500 \mathrm{ml}$ or g/ 500 - 750 litres of water or BAS 75101 F SC with a.i.(g) of 400 @ $1000 \mathrm{ml}$ or $\mathrm{g} / 500$ - 750 litres of water could be be used to control early blight of tomato safely without being toxic to plant. The similar observations on fungicidal phyto-toxicty were reported in previous experiments (Sahu et al., 2013; Saxena et al., 2016) ${ }^{[4,5]}$.

Table 1: Evaluation of bio-efficacy of BAS 75101 F SC against early blight disease of tomato during 2017-18

\begin{tabular}{|c|c|c|c|c|c|c|c|c|c|}
\hline \multirow{2}{*}{ Tr. No } & \multirow{2}{*}{ Treatment Details } & \multirow{2}{*}{ a.i. $(\mathrm{g})$} & \multirow{2}{*}{$\begin{array}{c}\text { Dosage/ha Formulation } \\
(\mathrm{g} \text { or } \mathrm{ml})\end{array}$} & \multirow{2}{*}{$\begin{array}{c}\text { Water } \\
\text { volume }(L)\end{array}$} & \multicolumn{3}{|c|}{$\%$ diseases PDI } & \multirow{2}{*}{ Mean } & \multirow{2}{*}{$\begin{array}{l}\text { Yields } \\
\text { (t/ha) }\end{array}$} \\
\hline & & & & & Before spray & I spray & II spray & & \\
\hline T1 & BAS $75101 \mathrm{~F} \mathrm{SC}$ & 120 & 300 & $500-750$ & $31.79(34.32)$ & $29.11(32.65)$ & $23.26(28.83)$ & 26.19 & 18.27 \\
\hline $\mathrm{T} 2$ & BAS $75101 \mathrm{~F} \mathrm{SC}$ & 160 & 400 & $500-750$ & $31.58(34.19)$ & $28.12(32.02)$ & $20.97(27.25)$ & 24.55 & 18.60 \\
\hline T3 & BAS $75101 \mathrm{~F} \mathrm{SC}$ & 200 & 500 & $500-750$ & $30.74(33.67)$ & $25.67(30.44)$ & $18.57(25.52)$ & 22.12 & 19.41 \\
\hline T4 & BAS 75002 F 400 g/l SC & 100 & 250 & $500-750$ & $32.34(34.65)$ & $29.33(32.79)$ & $26.43(30.94)$ & 27.88 & 17.83 \\
\hline $\mathrm{T} 5$ & Pyraclostrobin $20 \%$ WG & 100 & 500 & 500 & $32.75(34.90)$ & $31.57(34.18)$ & $28.23(32.09)$ & 29.9 & 17.20 \\
\hline T6 & Mancozeb 75\% WP & 1500 & 2000 & 750 & $32.32(34.64)$ & $32.00(34.45)$ & $29.77(33.06)$ & 30.89 & 16.36 \\
\hline $\mathrm{T} 7$ & Untreated Control & - & - & - & $32.52(34.76)$ & $39.67(39.03)$ & $57.07(49.06)$ & 48.37 & 13.55 \\
\hline & SEm \pm & & & & 0.39 & 1.74 & 1.58 & & 0.89 \\
\hline & $\mathrm{CD}(0.05)$ & & & & 1.20 & 5.38 & 4.87 & & 2.74 \\
\hline
\end{tabular}

Figures in parenthesis indicate arcsine values.

Table 2: Evaluation of bio-efficacy of BAS 75101 F SC against early blight disease of tomato during 2018-19

\begin{tabular}{|c|c|c|c|c|c|c|c|c|c|}
\hline \multirow{2}{*}{ Tr. No } & \multirow{2}{*}{ Treatment Details } & \multirow[b]{2}{*}{ a.i. $(\mathrm{g})$} & \multirow{2}{*}{\begin{tabular}{|c|} 
Dosage/ha \\
Formulation (g or $\mathrm{ml}$ )
\end{tabular}} & \multirow{2}{*}{$\begin{array}{c}\text { Water } \\
\text { volume }(L)\end{array}$} & \multicolumn{3}{|c|}{ \% diseases PDI } & \multirow{2}{*}{ Mean } & \multirow{2}{*}{ Yields (t/ha) } \\
\hline & & & & & Before spray & I spray & II spray & & \\
\hline $\mathrm{T} 1$ & BAS $75101 \mathrm{~F} \mathrm{SC}$ & 120 & 300 & 500 & $30.58(33.57)$ & $28.30(32.13)$ & $22.27(28.15)$ & 25.29 & $18.30(25.32)$ \\
\hline $\mathrm{T} 2$ & BAS $75101 \mathrm{~F} \mathrm{SC}$ & 160 & 400 & 500 & $30.97(33.81)$ & $27.23(31.45)$ & $19.32(27.07)$ & 23.28 & $18.63(25.57)$ \\
\hline T3 & BAS $75101 \mathrm{~F} \mathrm{SC}$ & 200 & 500 & 500 & $30.80(33.70)$ & $24.60(29.73)$ & $17.95(25.06)$ & 21.30 & $19.80(26.42)$ \\
\hline $\mathrm{T} 4$ & BAS 75002 F $400 \mathrm{~g} / 1 \mathrm{SC}$ & 100 & 250 & 500 & $30.27(33.37)$ & $28.27(32.11)$ & $25.23(30.15)$ & 26.73 & $17.85(24.99)$ \\
\hline T5 & Pyraclostrobin $20 \%$ WG & 100 & 500 & 500 & $30.70(33.64)$ & $30.60(33.58)$ & $27.27(31.47)$ & 28.94 & $17.80(24.95)$ \\
\hline T6 & Mancozeb 75\% WP & 1500 & 2000 & 750 & 30.67 (33.62) & 31.37 (34.06) & $28.57(32.30)$ & 29.97 & $16.72(24.13)$ \\
\hline \multirow[t]{3}{*}{$\mathrm{T} 7$} & Untreated Control & - & - & - & $30.83(33.73)$ & $40.03(39.25)$ & $50.70(45.40)$ & 45.37 & $13.82(21.82)$ \\
\hline & SEm \pm & & & & 0.24 & 1.60 & 1.55 & & 0.96 \\
\hline & $\mathrm{CD}(0.05)$ & & & & 0.74 & 4.91 & 4.80 & & 2.95 \\
\hline
\end{tabular}

Figures in parenthesis indicate arcsine values.

Table 3: Phytotoxicity effect of BAS 75101 F SC on tomato grown in field in kharief season of 2017-18

\begin{tabular}{|c|c|c|c|c|c|c|c|}
\hline \multirow[b]{2}{*}{$\begin{array}{c}\text { Day of observation } \\
\text { after spray }\end{array}$} & \multirow[b]{2}{*}{ Sl. No. } & \multirow[b]{2}{*}{ Treatments } & \multicolumn{5}{|c|}{ Phytotoxicity Symptoms } \\
\hline & & & $\begin{array}{l}\text { Leaf tips and } \\
\text { surface injury }\end{array}$ & Wilting & \begin{tabular}{|c|}
$\begin{array}{c}\text { Vein } \\
\text { clearing }\end{array}$ \\
\end{tabular} & Necrosis & $\begin{array}{c}\text { Epinasty and } \\
\text { hyponasty }\end{array}$ \\
\hline \multirow{4}{*}{ 1st Day } & \multirow{4}{*}{$\begin{array}{l}1 . \\
2 . \\
3 .\end{array}$} & \multirow{4}{*}{$\begin{array}{c}\text { BAS 75101 F @ } 500 \text { ml/ha } \\
\text { BAS 75101 F @ } 1000 \mathrm{ml} / \mathrm{ha} \text { Untreated } \\
\text { control }\end{array}$} & 0 & 0 & 0 & 0 & 0 \\
\hline & & & 0 & 0 & 0 & 0 & 0 \\
\hline & & & 0 & 0 & 0 & 0 & 0 \\
\hline & & & 0 & 0 & 0 & 0 & 0 \\
\hline \multirow{4}{*}{ 3rd Day } & 1. & \multirow{4}{*}{$\begin{array}{l}\text { BAS 75101 F @ } 500 \mathrm{ml} / \mathrm{ha} \\
\text { BAS 75101 F @ } 1000 \mathrm{ml} / \mathrm{ha} \\
\text { Untreated control }\end{array}$} & 0 & 0 & 0 & 0 & 0 \\
\hline & 2. & & 0 & 0 & 0 & 0 & 0 \\
\hline & 3. & & 0 & 0 & 0 & 0 & 0 \\
\hline & & & 0 & 0 & 0 & 0 & 0 \\
\hline \multirow{2}{*}{ 5th Day } & 1. & BAS 75101 F @ 500 ml/ha & 0 & 0 & 0 & 0 & 0 \\
\hline & 2. & BAS $75101 \mathrm{~F} @ 1000$ ml/ha & 0 & 0 & 0 & 0 & 0 \\
\hline
\end{tabular}




\begin{tabular}{|c|c|c|c|c|c|c|c|}
\hline & 3. & Untreated control & $\begin{array}{l}0 \\
0\end{array}$ & $\begin{array}{l}0 \\
0\end{array}$ & $\begin{array}{l}0 \\
0\end{array}$ & $\begin{array}{l}0 \\
0\end{array}$ & $\begin{array}{l}0 \\
0\end{array}$ \\
\hline 7th Day & $\begin{array}{l}1 . \\
2 . \\
3 .\end{array}$ & $\begin{array}{c}\text { BAS 75101 F @ } 500 \text { ml/ha } \\
\text { BAS75101 F @ } 1000 \text { ml/ha } \\
\text { Untreated control }\end{array}$ & $\begin{array}{l}0 \\
0 \\
0 \\
0\end{array}$ & $\begin{array}{l}0 \\
0 \\
0 \\
0\end{array}$ & $\begin{array}{l}0 \\
0 \\
0 \\
0\end{array}$ & $\begin{array}{l}0 \\
0 \\
0 \\
0\end{array}$ & $\begin{array}{l}0 \\
0 \\
0 \\
0\end{array}$ \\
\hline 10th Day & $\begin{array}{l}1 . \\
2 . \\
3 .\end{array}$ & $\begin{array}{c}\text { BAS 75101 F @ } 500 \text { ml/ha } \\
\text { BAS75101 F @ } 1000 \text { ml/ha } \\
\text { Untreated control }\end{array}$ & $\begin{array}{l}0 \\
0 \\
0 \\
0\end{array}$ & $\begin{array}{l}0 \\
0 \\
0 \\
0\end{array}$ & $\begin{array}{l}0 \\
0 \\
0 \\
0\end{array}$ & $\begin{array}{l}0 \\
0 \\
0 \\
0\end{array}$ & $\begin{array}{l}0 \\
0 \\
0 \\
0\end{array}$ \\
\hline
\end{tabular}

0: No Phytotoxicity

Table 4: Phytotoxicity effect of BAS 75101 F SC on tomato grown in field in kharief season of 2018-19

\begin{tabular}{|c|c|c|c|c|c|c|c|}
\hline \multirow[b]{2}{*}{$\begin{array}{c}\text { Day of observation } \\
\text { after spray }\end{array}$} & \multirow[b]{2}{*}{ Sl. No. } & \multirow[b]{2}{*}{ Treatments } & \multicolumn{5}{|c|}{ Phytotoxicity Symptoms } \\
\hline & & & $\begin{array}{l}\text { Leaf tips and } \\
\text { surface injury }\end{array}$ & Wilting & Vein clearing & Necrosis & $\begin{array}{c}\text { Epinasty } \\
\text { and hyponasty }\end{array}$ \\
\hline \multirow{3}{*}{ 1st Day } & 1. & BAS 75101 F @ 500 ml/ha & 0 & 0 & 0 & 0 & 0 \\
\hline & 2. & BAS75101 F @ 1000 ml/ha & 0 & 0 & 0 & 0 & 0 \\
\hline & 3. & Untreated control & 0 & 0 & 0 & 0 & 0 \\
\hline \multirow{3}{*}{ 3rd Day } & 1. & BAS 75101 F @ 500 ml/ha & 0 & 0 & 0 & 0 & 0 \\
\hline & 2. & BAS 75101 F @ 1000 ml/ha & 0 & 0 & 0 & 0 & 0 \\
\hline & 3. & Untreated control & 0 & 0 & 0 & 0 & 0 \\
\hline \multirow{3}{*}{ 5th Day } & 1. & BAS $75101 \mathrm{~F} @ 500$ ml/ha & 0 & 0 & 0 & 0 & 0 \\
\hline & 2. & BAS75101 F @ 1000 ml/ha & 0 & 0 & 0 & 0 & 0 \\
\hline & 3. & Untreated control & 0 & 0 & 0 & 0 & 0 \\
\hline \multirow{3}{*}{ 7th Day } & 1. & BAS 75101 F @ 500 ml/ha & 0 & 0 & 0 & 0 & 0 \\
\hline & 2. & BAS 75101 F @ 1000 ml/ha & 0 & 0 & 0 & 0 & 0 \\
\hline & 3. & Untreated control & 0 & 0 & 0 & 0 & 0 \\
\hline \multirow{3}{*}{ 10th Day } & 1. & BAS $75101 \mathrm{~F} @ 500$ ml/ha & 0 & 0 & 0 & 0 & 0 \\
\hline & 2. & BAS75101 F @1000 ml/ha & 0 & 0 & 0 & 0 & 0 \\
\hline & 3. & Untreated control & 0 & 0 & 0 & 0 & 0 \\
\hline
\end{tabular}

0: No Pyhtotoxicity

\section{References}

1. CIB. Manual for testing phytotoxicity of pesticides on agricultural crops. Pesticides Association of India, New Delhi, 1989, 120.

2. Gomez KA, Gomez AA. Statistical procedures for agriculture research. 2nd edition, John Wiley and Sons, 1986, pp. 680.

3. Patel RL, Chaudhary RF. Management of Alternaria solani causing early blight of tomato with fungicides. J Plant Dis. Sci. 2010; 5:65-67.

4. Sahu DK, Khare CP, Singh HK, Thakur MP. Evaluation of newer fungicide for management of early blight of tomato in Chhattisgarh. The Bioscan. 2013; 8(4):12551259.

5. Saxena A, Birinchi Kumar Sarma, Harikesh Bahadur Singh. Effect of azoxystrobin based fungicides in management of chilli and tomato diseases. Proc. Natl. Acad. Sci., India, Sect. B Biol. Sci. 2016; 86(2):283-289.

6. Sharma RK, Patel DR, Chaudhari DR, Kumar V, Patel MM. Effect of some fungicides against early blight of tomato (Lycopersicon esculentum Mill.) caused by Alternaria solani (Ell. \& Mart.) Jones and Grout and their impact on yield. Int. J Curr. Microbiol. App. Sci. 2018; 7(7):1395-1401.

7. Tiwari RKS, Rajput ML, Singh A. Effect of sowing dates and spray schedule of mancozeb on early blight Alternaria solani of potato. Indian J Plant Prot. 2004; 32(2):61-64.

8. Wheeler BEJ. An Introduction of plant disease, John Wiley and Sons, 1969.

9. Yadav OP, Dabbas MR. Efficacy of fungicides in the management of early blight of tomato (Alternaria solani). Int. J Plant Prot. 2012; 5(2):413-416. 